\title{
Peer Pressure and Self-Efficacy as Predictors of Risky Sexual Behaviour among in-School Adolescents in Makurdi Local Government
}

\author{
Rimande Ubandoma Joel MBBS ${ }^{1}$, Tomen Egbe Agu, $\mathrm{PhD}^{2}$, Dzer Benjamin Terzungwe, $\mathrm{PhD}^{3^{*}}$ \\ ${ }^{1,2}$ Department of Public Health, Taraba State University, Jalingo \\ ${ }^{3}$ Department of Nursing, College of Health Sciences, Benue State University, Makurdi \\ *Corresponding Author
}

\begin{abstract}
The study "peer pressure and self-efficacy as predictors of risky sexual behavior among in-school adolescents in Makurdi local government" was carried out with the following objectives to find out if; peer pressure will predict risky sexual behaviors among in-school adolescents in Makurdi Local Government, selfefficacy will predict risky sexual behaviors among in-school adolescents in Makurdi Local Government, peer pressure and Self-efficacy will jointly predict risky sexual behaviors among inschool adolescents in Makurdi Local Government. The study was anchored on the Albert Bandura's social learning / cognitive theory and Dweck and colleagues' implicit theories of peer relationships. Using the Taro Yamane's formula, the sample size of the study was 400 . The participants were all sampled from Tiley Gyado Secondary School, Jewel Academy, Airforce Secondary School, Elite Secondary School, Pardopas Harmony Secondary School, and Community Secondary school all from Makurdi local government. Of the whole 400 participants age wise, 25(6.3\%), 17(4.3\%), 72(18\%), 127(31.8\%), 69(16.5\%), $66(16.5 \%)$ and $24(6 \%)$ participant were $12,13,14,15,16,17$ and 18 years respectively. Regarding participant's sex, 218 respondents represented by $(54.5 \%)$ were males while the remaining $182(45.5 \%)$ were females. Furthermore, 352(88\%) were Christian as $42(12 \%)$ were Islam religious wise. Pertaining tribe, Tiv was highly represented with 204(51\%) following by Idoma $80(20 \%)$ while Igede maintained $67(16.8 \%)$ as others constituted 49(12.3\%). Also, demographically it was shown that $226(56.5 \%)$ were of the junior class (JSS 1-3) while 174(43.5\%) represented the senior class (SS 1-3). Findings of the study showed that, peer pressure significantly predicted risky sexual behavior among in-school adolescents in Makurdi metropolis [R $=.286$ and $\left.R^{2}=.082 ; F(1,398)=35.459 ; p<.001\right] ;$ that selfefficacy significantly predicted risky sexual behavior among inschool adolescents in Makurdi metropolis $\left[R=.726\right.$ and $R^{2}=$ $.527 ; F(1,398)=443.782 ; p<.001]$; that peer pressure and selfefficacy significantly and jointly predicted risky sexual behavior among in-school adolescents in Makurdi metropolis $[R=.730$ and $\left.R^{2}=.533 ; F(2,397)=226.576 ; p<.001\right]$. also findings further showed that there was a significant main effect of tribe on risky sexual behavior among in-school adolescents in Makurdi metropolis $[F(3,389)=6.046 ; p<.001]$. It was therefore recommended that, care givers and parents should ensure that only positive peer pressures are allowed around students. As the implication of negative peer pressure can result to risky sexual behavior which may result to unwanted pregnancies or being infected with sexually transmitted diseases amongst others; school curriculums and organizations should allow for policies
\end{abstract}

and teachings that will discourage risky sexual behaviors amongst adolescents generally (in-school adolescents especially); there should be a watch on students self-efficacies as it is key to what they (in-school adolescents) do per time.

Keywords: Peer-Pressure, Self-Efficacy, Risky Sexual Behavior, Adolescent, In-School Adolescents.

\section{INTRODUCTION}

$\mathrm{O}$ ne of the current challenges in the world today is the prevention and control of sexually transmitted diseases among adolescents and youths. In sub-Saharan Africa (SSA) more than elsewhere, young people within this age bracket remains the most threatened, accounting for half of all new HIV infections. Risky sexual behaviors refer to individual's sexual practices that may increase the susceptibility of person to the risk of sexually transmitted infections (STIs) including HIV/AIDS, unplanned pregnancies and psychological disorders. Based on the review of published articles (Messervey \& Kusumakar, 2000; CDC, 2011; Hamilton Martin \& Ventura, 2011) some of these behaviors include unprotected sexual intercourse, having multiple sexual partners, early sexual initiation, sexual intercourse with commercial sex workers and bartering sex for money, goods or other favors.

Although there is no international consensus on the definition of adolescence, the United Nations (UN) defines an adolescent as an individual who falls into the period following the onset of puberty during which a young person develops from a child into an adult. Numerically from $8-18$. The UN estimated that around 1.2 billion people in the world are the adolescent aged $10-19$ years which accounts $17.6 \%$ of the total population. More than $80 \%$ of them live in developing countries. Nigeria with a very young population is the most populous country in sub-Saharan Africa. The majority of her population is below the age of 25 years, with 22 percent of the country's population between the ages of 10-19 years. This is where the adolescents seats. Adolescent which subsequently are regarded as youth make up the greatest proportion of the population in Sub-Saharan Africa (SSA), with almost onethird of the population between the ages of 10 and 19 (Alemu et al, 2007 and Rafael et al., 2015). 
The adolescent period generally and specifically in-school adolescent is a complex maturational and developmental process which varies across individuals and cultures. Successful passage through this portal to adulthood results does not only lay on biological maturity, the secure sense of self, the ability to enjoy close friendships and group belonging, and the mental capacity to deal with the onslaught of life's challenges but also, students' mingling despite different backgrounds, and behaviors that could be classed deviant. Hence, its management is of great essence.

However, failure to manage adequately the physical, emotional, cognitive, and moral unfolding of adolescence can lead to a deviant identity behavioral anomalies and risky sexual behaviors some of which are found among in-school adolescents. (Kruger, Gouws and Dicker, 2011). Upon various studies it has been observed that varying degree of behavioral problems ranging from violent related behaviors, substance use and misuse, and participation in risky sexual behaviors often occur amongst adolescents. Each of these problems is not without its burden. As it is with developed nations of the world so it is with Nigeria and Makurdi. Many have wondered what the root cause of risky sexual behavior amongst inschool adolescent is. Upon several guessing it was thought that peer-pressure and self-efficacy could be responsible for risky sexual behavior amongst in-school adolescents.

Peer-pressure which is the influence of one individual on another has been viewed to play an integral role in the indulgent of in-school adolescents in risky sexual behaviors. As adolescents grow, they tend to be more active and sensitive to sexual activities. Many are novice to some of the experiences of the pain, discomfort and unexplainable hormonal changes that unfolds as they progress in their adolescent stages. As a result of this they get introduced to some behaviors that are morally uncalled for but yet were viewed to be the only way out of their miseries. Some of their activities may include; bare backing, i.e. sex without a condom, mouth-to-genital contact, starting sexual activity at a young age, having multiple sex partners, having a high-risk partner, someone who has multiple sex partners or infections, anal sex, sex with a partner who has ever injected drugs amongst several others. All of these may seem not have been issues of considerations, not until the appetite for sex of an inschool adolescent increases, injections, drug usage, prostitutions, abortions and the acquiring of sexual transmitted diseases such as HIV-Aids, Gonorrhea amongst several other sex related social ills becomes obvious and uncontrollable. This directly or indirectly is linked with one's self efficacy.

On the other hand self-efficacy which is an individual's confidence in his/her own ability to apply control over his or her own motivation, behavior and social environment. Students most often when saddled with pressures from peers lack the ability to control themselves, the situation around and their environment. This in turn results to behaviors that have rendered many useless and claimed lots of life through diseases acquired through risky sexual behaviors.

\section{Statement of Problem}

Risky sexual behavior is on the increase. Worrisome aspect of it is the prevalence of risky sexual behavior among adolescents at large and in-school adolescents in particular. Risky sexual behavior predisposes young people to a variety of sexuality associated problems including unwanted pregnancies, HIV and other sexually transmitted diseases. Strategies to prevent the spread of HIV and other sexually transmitted infections and reduce mortality rate have focused on abstinence, condom use and delayed sexual activity among people that engage in sexual activities. However available evidences show that significant proportion of adolescents are engaged in risky sexual behaviors that expose them to a variety of sexually trans-mitted infections including HIV. Over time this has been the case with in-school adolescents (UNAIDS, 2014 and Famutimi \& Olowatoyin, 2014).

Approximately half of the new HIV infections globally occur in the age group 15 to 24 years some of which are still inschool adolescents. Although significant proportion of young people (students inclusive) in Africa and Nigeria are known to be involved in risky sexual behavior such as early sexual initiation, multiple partner sexual relationships, low use of condom, and sex in ex-change of money identifying the factors associated with these behaviors so far have been focused on individual- level factors. This simply implies that the involvement of an in-school adolescent in risky sexual behavior is self-decisive. This self-decision can be simply tied to peer-pressure and self-efficacy. Hence, peer-pressure and self-efficacy in an adolescent may perhaps trigger or kill risky sexual behaviors among in-school adolescents. Thus this research seeks to ascertain if peer-pressure and self-efficacy predicts risky sexual behaviors among in-school adolescents in Makurdi Local Government.

\section{Aim and Objectives of Study}

This study seeks to find out if peer-pressure and self-efficacy as predictors of risky sexual behaviors among in-school Adolescents in Makurdi Local Government. The objectives are to find out if:

i. Peer pressure will predict risky sexual behaviors among in-school adolescents in Makurdi Local Government.

ii. Self-efficacy will predict risky sexual behaviors among in-school adolescents in Makurdi Local Government.

iii. Peer pressure and Self-efficacy will jointly predict risky sexual behaviors among in-school adolescents in Makurdi Local Government.

\section{Research Question}

i. Does Peer pressure predict risky sexual behaviors among in-school adolescents in Makurdi Local Government? 
ii. Does Self-efficacy predict risky sexual behaviors among in-school adolescents in Makurdi Local Government?

iii. Does Peer pressure and Self-efficacy jointly predict risky sexual behaviors among in-school adolescents in Makurdi Local Government?

\section{Hypotheses}

i. Peer pressure will significantly predict risky sexual behaviors among in-school adolescents in Makurdi Local Government.

ii. Self-efficacy will significantly predict risky sexual behaviors among in-school adolescents in Makurdi Local Government.

iii. Peer pressure and Self-efficacy will significantly jointly predict risky sexual behaviors among inschool adolescents in Makurdi Local Government.

Scope of Study

This study is limited to Makurdi Local Government. This is one of the twenty-three local governments in Benue State of Nigeria. More specifically this study is limited to in-school adolescents in Makurdi bearing in mind the variables of the research understudy (that is, risky sexual behaviors, peerpressure and self-efficacy).

\section{METHODS AND MATERIALS}

\section{Design}

This research employed the survey design in which the respondents were requested to respond to a set of questionnaire items to examine peer-pressure and self-efficacy as predictors of risky sexual behaviors among in-school adolescents in Makurdi Local Government. In essence, survey design is one in which a group of people is studied by collecting and analyzing data from a few people considered to be a representative sample of the entire population (Emaikwu, 2012). The survey design specifies how the data was collected and analyzed.

\section{Settings}

The research settings is Makurdi Local Government Area. Makurdi is the capital of Benue state, east-central Nigeria. It lies on the south bank of the Benue River. In 1976, following the division of Benue-Plateau state into two states, Makurdi was selected as the capital of Benue state (Anyo 2012). Makurdi's population as a Local Government according to the 2006 census was 406,555 while in 2007; Makurdi had an estimated population of 500,797. This implies that Makurdi local government in terms of population is consistently increasing. Makurdi local government has a land mass of 34,059 square kilometer with eleven (11) Council wards. Makurdi is located in the middle belt are of Nigeria, situated at the ban of the Benue Valley and is bothered on the west and north by Katsina and Doma Local government area, on the south by both Gwer and Gwer-West Local Government Areas of Benue State.
Makurdi Local government is predominantly a Tiv speaking area. Other ethnic groups found settled in the area include, Idoma, Igede, Etulo, Jukun, Igbo, Yoruba Hausa among others. Makurdi is also a tourist center with the presence of River Benue. The J.S. Tarkaa foundation structure and the Makurdi Zoological garden situated inside Benue State University, Makurdi. Also, the location of the Nigerian Air force Base, the Benue State University, the Federal University of Agriculture and the National Open University makes Makurdi attractive. The establishments of markets including the modern market, North bank market, High-level market and Wurukum market, motor parks and gardens generate revenue to the local government.

However, Makurdi Local Government Area's eleven (11) council wards are namely; Agan ward, Ankpa ward, Wadata ward, Bar central mission ward, Clerk ward, Fiidi ward, Mbalagh ward, Wailomayo ward, Modern market ward and North bank1 and North bank 2 wards. While across these eleven council wards, there are areas referred to as metropolis. Makurdi metropolis is made up of North bank, Federal locust, Akpehe, Wurukum, High level, Logo, Modern market, Ankpa Quarters, Kanshio, Idye, Fiddi, Airforce Base, Gyado villa, Benue State University, Gaadi, Apii and Lobi quarters with one or more secondary schools to each of them respectively.

Furthermore, in the metropolitan areas of Makurdi there exists a range of schools that allows virtually people of all agebrackets gain access to education. Chief of them all is the educational settings made available for the adolescents (i.e., the secondary school students). This therefore gives room form what is known as the in-school adolescents. This study therefore intends to examine how peer-pressure and selfefficacy predicts risky sexual behaviours among in-school Adolescents in Makurdi Local Government.

\section{Participants}

For the purpose of the study participants of the study were inschool adolescents of secondary school in the Makurdi metropolitan areas. Specifically, students of Tiley Gyado Secondary School, Jewel Academy, Air Force Secondary School, Erlite Secondary School, Padopads Harmony Secondary School, and Community Secondary School were randomly selected as participants.

The demographic data of the participants were represented as follows: Age wise, 25(6.3\%), 17(4.3\%), 72(18\%), $127(31.8 \%), 69(16.5 \%), 66(16.5 \%)$ and $24(6 \%)$ participant were age $12,13,14,15,16,17$ and 18 years respectively. Regarding participant's sex, 218 respondents represented by $(54.5 \%)$ were males while the remaining $182(45.5 \%)$ were females. Furthermore, 352(88\%) were Christian as $42(12 \%)$ were islam religious wise. Pertaining tribe, Tiv was highly represented with 204(51\%) following by Idoma $80(20 \%)$ while Igede maintained $67(16.8 \%)$ as others constituted 49(12.3\%). Also, demographically it was shown that $226(56.5 \%)$ were of the junior class (JSS 1-3) while $174(43.5 \%)$ represented the senior class (SS 1-3). 


\section{Sampling}

In sampling, the simple random sampling technique was used for this research. Based on findings, from the eleven council wards; the following metropolitan areas includes; North Bank Federal Locust, Gyado villa Gaadi, Apii, Lobi, High level, Ankpa Quarters, Modern market, Benue state University, Kanshio, Idye, Akpehe Fiidi, Airforce base, Wurukum, and Wadata out of which seven schools were selected and their population are detailed as follows: Tiley Gyado Secondary School (223)- North Bank, Jewel Academy(100) Wurukum, Airforce Secondary School (102) - Airforce, Elite Secondary School (372) Modern Market, Pardopas Harmony Secondary School(450)-High Level, and Community Secondary School (164) Wadata. This six schools were selected and total population summed to be 1411 .

Sample size determination

$n=\frac{N}{1+N(e)}$

$\mathrm{n}=$ Sample size

$\mathrm{N}=$ Total population

$\mathrm{e}=$ level of significance (.05)

$1 \& 2=$ Constant

$\mathrm{N}=1411$

\section{Calculation}

$n=\frac{1411}{1+1411(0.05)}$ 2

$n=\frac{1411}{1+1411 \times 0.05 \times 0.05}$

$n=\frac{1411}{1+1411 x(0.0025)}$

$n=\frac{1411}{1+3.527}$

$\mathrm{n}=\frac{1411}{4.527}$

$\mathrm{n}=399.49$

Approximately $n=400$

Therefore the sample size is $=400$.

\section{Instruments}

\section{Sexual Risk Survey Scale by Turchik and Garske (2009)}

The SRS is a 23-item questionnaire developed by Turchik and Garske (2009), which assesses the prevalence of sexual risk behavior among a sample of college students. Although Turchik and Garske (2009) reported the following subscales, a) Sexual Risk Taking with Uncommitted Partners, b) Risky Sex Acts, c) Impulsive Sexual Behaviors, d) Intent to Engage in Risky Sexual Behaviors, and e) Risky Anal Sex Acts, with respective reliability coefficients $0.88,0.80,0.78,0.89$, and
0.61 , the present study analyzed the dimensionality of the SRS more rigorously, and revealed a different set of underlying subscales.

\section{Self-Efficacy Questionnaire by Peter Muris 2001}

The self-efficacy questionnaire (SEQ) for developed by Peter Muris in 2001. The SEQ-C contains 24 items that are hypothesized to represent three domains of self-efficacy: (1) social self-efficacy that has to do with the perceived capability for peer relationships and assertiveness; (2) academic selfefficacy that is concerned with the perceived capability to manage one's own learning behavior, to master academic subjects, and to fulfill academic expectations; and (3) emotional self-efficacy that pertains to the perceived capability of coping with negative emotions Each item has to be scored on a 5-point scale with $1 \mathrm{D}$ not at all and $5 \mathrm{D}$ very well.

Peer Pressure scale by Santor, Messervey, Kusumakar (2000).

The 30 - item scale was developed with peer pressure, popularity and conformities in adolescent boys and girls. The developers developed and validated short measures of peer pressure, peer conformity, and popularity in a sample $(\mathrm{n}=$ 148) of adolescent boys and girls in grades 11 to 13. Results showed that all measures constructed for the study were internally consistent. Although all measures of peer pressure, conformity, and popularity were intercorrelated, peer pressure and peer conformity were stronger predictors of risk behaviors than measures assessing popularity, general conformity, or dysphoria. Despite a simplified scoring format, peer conformity vignettes were equal to if not better than the peer pressure measures in predicting risk behavior.

\section{Validation of Report}

The questionnaires were first administered to a smaller sample size of participants to ascertain whether or not and to what extent will the instruments test what is required for it to test. Upon conclusion, the following validity report was made.

\section{Reliability of Peer Pressure}

Result of the validation of peer pressure shows that, the scale has Guttman split half reliability coefficient of .671 and internal consistency of .801Conbach's alpha indicating high consistency. When item analysis was conducted, items19 (-.038), 21 (.206), 22 (.195), 23 (.024), 24 (.216), 26 (.081), 27 (.019) and 30 (.115) could not meet up with Cristobal, Flavián, \& Guinalíu, (2007)'s criterion for returning items on the scale which stated that an item must correlate at least .30 with the total correlation. Based on this criterion, items 19, 21, 22, 23, 24, 26, 27 and 30 should be removed.

\section{Reliability of Self-Efficacy}

On the basis of self-efficacy, the result indicated that the scale has Guttman split half reliability coefficient of .576 and internal consistency of .798Conbach's alpha indicating 
high consistency. When item analysis was conducted, items 7 (.279), 9 (.249), 10 (-.080), $11(.103), 12(.236), 14$ (.135), 15 (.195), 16 (.247), 18 (.284) and 23 (.248) could not meet up with Cristobal, Flavián, \& Guinalíu, (2007)'s criterion for returning items on the scale which stated that an item must correlate at least .30 with the total correlation. Based on this result, items $7,9,10,11,12,14,15,16,18$ and 23 should be removed from the scale for use in this study.

\section{Reliability for Sexual Behavior}

On the basis of sexual behavior, the result indicated that the scale has Guttman split half reliability coefficient of .898 and internal consistency of .816Conbach's alpha indicating high consistency. When item analysis was conducted, items 3 (.205), 4 (.197), 6 (.259), 9 (.240), 11 (.205), 12 (.197), 14 (.259) and 17 (.240) could not meet up with Cristobal, Flavián, \& Guinalíu, (2007)'s criterion for returning items on the scale which stated that an item must correlate atlease. 30 with the total correlation. Based on this result, items 3, 4, 6, 9, $11,12,14$ and 17 should be removed from the scale for this study.

\section{Reliability of All Scales}

On the reliability coefficient of all the items, the result indicated that internal consistency of .931 Cronbach's alpla was obtained which indicate a very high internal consistency.

\section{Validity}

On validity, face validity was conducted as well as discriminant and convergent validity and the validity result shows that there was a significant relationship between selfefficacy and peer pressure $[\mathrm{r}=.303$; $\mathrm{p}<.05]$, sexual behavior and peer pressure $[\mathrm{r}=.297 ; \mathrm{p}<.05]$ and sexual behavior and self-efficacy $[\mathrm{r}=.731 ; \mathrm{p}<.05]$.

\section{Procedure}

The researcher engaged three (3) research assistants from the department of psychology, Benue State University, Makurdi in order to help in the distribution and retrieval of copies of the questionnaire that were distributed among participants with the intent to be able to explain portions of the questionnaires to the in-school adolescents and to be able to round off session on time. Prior to the distribution of questionnaires a detailed explanation of the aim and objective of this research was made known to the research assistants in order to help curtail or reduce extraneous variables that may infiltrate the result of the research.

Participation in this research was voluntary as consent were sought from all adolescents (that are in-schools) with the letter of introduction and confidentiality of information been assured by the researcher.

\section{Data Analysis}

The data for the study was analyzed using descriptive and inferential statistics. The descriptive statistics involving frequencies, percentages and tables was used to summarize respondents" demographic information. On the other hand, inferential statistics involving the ANOVA was used to test the hypotheses via the statistical package for social sciences (SPSS) Version 21.

\section{RESULTS}

\section{Hypotheses Testing}

\section{Hypothesis 1}

This hypothesis stated that peer pressure will significantly predict risky sexual behavior among in-school adolescents in Makurdi metropolis. This hypothesis was tested using regression analysis and the result is presented table 1 .

Table 1: Simple linear regression analysis showing peer pressure as a predictor of risky sexual behavior among in-school adolescents in Makurdi metropolis

\begin{tabular}{|c|c|c|c|c|c|c|c|c|}
\hline $\mathrm{DV}$ & $\begin{array}{c}\text { Predictor } \\
(\mathrm{s})\end{array}$ & $\mathrm{R}$ & $\mathrm{R}^{2}$ & $\mathrm{~F}$ & $\mathrm{df}$ & $\beta$ & $\mathrm{T}$ & $\mathrm{p}$ \\
\hline $\begin{array}{c}\text { Risky } \\
\text { Sexual } \\
\text { Behavior }\end{array}$ & Constant & .286 & .082 & $35.459^{* *}$ & 1,398 & & 11.555 & $<.001$ \\
\hline & $\begin{array}{c}\text { Peer } \\
\text { Pressure }\end{array}$ & & & & & .286 & 5.955 & $<.001$ \\
\hline
\end{tabular}

$* *$ Sig at 0.001

Result in table 1 shows that peer pressure significantly predicted risky sexual behavior among in-school adolescents in Makurdi metropolis $\left[\mathrm{R}=.286\right.$ and $\mathrm{R}^{2}=.082 ; \mathrm{F}$ $(1,398)=35.459 ; \mathrm{p}<.001]$. Observation $\left(\mathrm{R}^{2}=.230\right)$ shows that peer pressure significant explains $8.2 \%$ in the variation on risky sexual behavior among in-school adolescents. The beta value $[\beta=.286]$ shows a positive score meaning that the more pressure peers receive from friends, the more they engage in risky sexual behavior among in-school adolescents in Makurdi metropolis. Based on this result, hypothesis one which stated that 'peer pressure will significantly predict risky sexual behavior among in-school adolescents in Makurdi metropolis' was therefore accepted.

\section{Hypothesis 2}

This hypothesis stated that self-efficacy will significantly predict risky sexual behavior among in-school adolescents in Makurdi metropolis. This hypothesis was tested using linear regression analysis and the result is presented in table 2 . 
Table 2: Simple linear regression analysis showing self-efficacy as a predictor of risky sexual behaviour among in-school adolescents

\begin{tabular}{|c|c|c|c|c|c|c|c|c|}
\hline DV & Predictor(s) & $\mathrm{R}$ & $\mathrm{R}^{2}$ & $\mathrm{~F}$ & $\mathrm{df}$ & $\beta$ & $\mathrm{T}$ & $\mathrm{p}$ \\
\hline $\begin{array}{c}\text { Risky Sexual } \\
\text { Behaviour }\end{array}$ & Constant & .726 & .527 & $443.782^{* *}$ & 1,398 & & 7.129 & $<.001$ \\
\hline & Self-efficacy & & & & & .726 & 21.066 & $<.001$ \\
\hline
\end{tabular}

\section{** Sig at 0.001}

Result in table 2 shows that self-efficacy significantly predicted risky sexual behavior among in-school adolescents in Makurdi metropolis $\left[\mathrm{R}=.726\right.$ and $\mathrm{R}^{2}=.527 ; \mathrm{F}(1,398)=$ $443.782 ; \mathrm{p}<.001]$. Observation of $\mathrm{R}^{2}=.527$ shows that selfefficacy significantly explains $52.7 \%$ of the variation in risky sexual behavior among in-school adolescents in Makurdi metropolis. The beta value $[\beta=.726]$ shows a positive score meaning in-school adolescents who scored high in selfefficacy significantly scored high in risky sexual behavior while in-school adolescents who scored low on self-efficacy significantly scored low on risky sexual behavior. Based on this result, hypothesis two which stated that 'self-efficacy will significantly predict risky sexual behavior among in-school adolescents in Makurdi Metropolis' was therefore upheld.

\section{Hypothesis 3}

This hypothesis stated that peer pressure and self-efficacy will significantly and jointly predict risky sexual behavior among in-school adolescents in Makurdi metropolis. This hypothesis was tested using multiple regression analysis and the result is presented in table 3 .

Table 3: Multiple regression analysis summary table showing the joint prediction of peer pressure and self-efficacy on risky sexual behavior among in-school adolescents in Makurdi metropolis

\begin{tabular}{|c|c|c|c|c|c|c|c|c|}
\hline DV & Predictor(s) & $\mathrm{R}$ & $\mathrm{R}^{2}$ & $\mathrm{~F}$ & $\mathrm{df}$ & $\beta$ & $\mathrm{T}$ & $\mathrm{p}$ \\
\hline $\begin{array}{c}\text { Risky Sexual } \\
\text { Behavior }\end{array}$ & Constant & .730 & .533 & $226.576^{* *}$ & 2,397 & & 3.918 & $<.001$ \\
\hline & Peer Pressure & & & & & .280 & 9.227 & $<.001$ \\
\hline & Self-Efficacy & & & & & .703 & 19.586 & $<.001$ \\
\hline
\end{tabular}

** Sig at 0.001

Result in table 3 shows that peer pressure and selfefficacy significantly and jointly predicted risky sexual behavior among in-school adolescents in Makurdi metropolis $\left[\mathrm{R}=.730\right.$ and $\left.\mathrm{R}^{2}=.533 ; \mathrm{F}(2,397)=226.576 ; \mathrm{p}<.001\right]$. Observation of coefficient of determination $\left[\mathrm{R}^{2}=.533\right]$ shows that both peer pressure and self-efficacy significantly and jointly explains $53.3 \%$ variation in risky sexual behavior among in-school adolescents in Makurdi metropolis. Based on this result, hypothesis three which stated that 'peer pressure and self-efficacy will significantly and jointly predict risky sexual behavior among in-school adolescents in Makurdi Metropolis' was therefore accepted.

\section{Incidental Findings}

Other demographic characteristics that were included in the research were not captured in the statement of hypotheses. This section seeks to identify if there will be a significant main and interactive effect of sex, religion and tribe on risky sexual behavior among in-school adolescents in Makurdi metropolis. This was conducted using univariate analysis of variance and the result is presented in table 4 .

Table 4: Univariate analysis of variance summary table for the main and interactive effect of sex, religion and tribe on risky sexual behavior among inschool adolescents in Makurdi metropolis

\begin{tabular}{|c|c|c|c|c|c|c|}
\hline Source & $\begin{array}{c}\text { Type III } \\
\text { SSq }\end{array}$ & df & MSq & F & Sig & $\eta$ \\
\hline Sex & 13.856 & 1 & 13.856 & .210 & .647 & .001 \\
\hline
\end{tabular}

\begin{tabular}{|c|c|c|c|c|c|c|}
\hline Religion & .691 & 1 & .691 & .010 & .919 & .000 \\
\hline Tribe & 1195.654 & 3 & 398.551 & 6.046 & .000 & .045 \\
\hline $\begin{array}{c}\text { Sex } \\
\text { Religion } \\
\text { Tribe }\end{array}$ & 324.145 & 2 & 324.145 & 2.356 & .156 & .014 \\
\hline Error & 25642.074 & 389 & 65.918 & & & \\
\hline Total & 707128.000 & 400 & & & & \\
\hline
\end{tabular}

$\mathrm{R}^{2}=.149$ and Adjusted $\mathrm{R}^{2}=.127$

Result in table 4 shows that there was a significant main effect of tribe on risky sexual behavior among in-school adolescents in Makurdi metropolis $[\mathrm{F}(3,389)=6.046 ; \mathrm{p}<.001]$. On the other hand, the result in table 4 shows that there was no significant main effect of $\operatorname{sex}[\mathrm{F}(1,389)=.210 ; \mathrm{p}>.05]$ and religion $[\mathrm{F}(1,389)=.919 ; \mathrm{p}>.05]$ on risky sexual behavior among in-school adolescents in Makurdi metropolis.

In the same vein, the result shows that there was no significant interactive effect of sex, religion and tribe on risky sexual behavior among in-school adolescents in Makurdi metropolis $[\mathrm{F}(2,389)=2.356 ; \mathrm{p}>.05]$.

\section{CONCLUSION}

This study assessed the influence of peer pressure and selfefficacy on risky sexual behavior among in-school adolescents in Makurdi metropolis. The present study has shown that there was a significant joint influence of peer-pressure and self- 
efficacy on risky sexual behavior among in-school adolescents in Makurdi Metropolis. Also there is a significant independent influence of peer pressure and self-efficacy on risky sexual behavior among in-school adolescents in Makurdi metropolis. As findings proved, a high record of self-efficacy implies a high tendency of engaging in risky sexual behaviors. On the contrary, a low record of self-efficacy implies a low tendency of engaging in risky sexual behaviors. Thus, peer pressure can increase or decrease peer pressure. Hence, the more pressure received from peers the more risky behaviors an adolescent is likely to display

\section{RECOMMENDATIONS}

Based on the findings of this study, the following recommendations are made;

i. Care givers and parents should ensure that only positive peer pressures are allowed around students. As the implication of negative peer pressure can result to risky sexual behavior which may result to unwanted pregnancies or being infected with sexually transmitted diseases amongst others.

ii. School curriculums and organizations should allow for policies and teachings that will discourage risky sexual behaviors amongst adolescents generally (inschool adolescents especially).

iii. There should be a watch on students self-efficacies as it is key to what they (in-school adolescents) do per time.

\section{REFERENCES}

[1] Abels MD, Blignaut RJ. (2011). Sexual risk behavior among sexually active first year students at the University of the Western Cape, South Africa. African Journal of AIDS Research.;10(3): 255-61.

[2] Ajzen, I. (1991). The Theory of Planned Behavior. Organizational Behavior and Human Decision Processes, 50, p.179-211.

[3] Alemu H, Mariam DH, Belay KA, Davey G. (2007). Factors Predisposing Out-of-School Youths to HIV/AIDS-related Risky Sexual Behaviour in Northwest Ethiopia. Ethiopia J Health Popul Nutr. 2007; 344-350.

[4] Allen, J.P., Porter, M.R. \& McFarland, F.C. (2006). Leaders and followers in adolescent close friendships: Susceptibility to peer influence as a predictor of risky behavior, friendship instability, and depression. Development and Psychopathology, 18, 155-172. and development. Philadelphia: Psychology Press

[5] Anderson, E. S., Winett, R. A., \& Wojcik, J. R. (2000). Socialcognitive determinants of nutrition behavior among supermarket food shoppers: A structural equation analysis. Health Psychology, 19(5), p. 479-486.

[6] Anyo, (2012). Benue State History. An online material

[7] Averett S, Corman H, Reichman NE. (2013); Effects of Overweight on Risky Sexual Behavior of Adolescent Girls. Economic Inquiry. 51(1):605-619.

[8] Bandura, A. (1986). Social foundations of thought and action: A social cognitive theory. Upper Saddle River, NJ: Prentice Hall

[9] Bandura, A. (1993). Perceived self-efficacy in cognitive development and functioning. Educational Psychologist, 28(2), 117-148. doi: 10.1207/s15326985ep2802_3.

[10] Bandura, A. (1997). Self-efficacy: The exercise of control. New York: Freedom and Company.

[11] Bandura, A. (1997). Self-efficacy: The exercise of control. New York: Freeman
[12] Berndt, T.J. \& Ladd, G.W. (1989). Peer relationships in child development. New York: Wiley \& Sons, Inc.

[13] Bingenheimer, J.B., Asante, E and Ahiadeke, C (2015). Peer Influences on Sexual Activity among Adolescents in Ghana. Stud Fam Plann. Author manuscript; available in PMC 2016 Mar 1.

[14] Brener, N. D., Kann, L., Kinchen, S. A., Grunbaum, J. A., Whalen, L., Eaton, D., ... \& Ross, J. G. (2004). Methodology of the youth risk behavior surveillance system. MMWR. Recommendations and reports: Morbidity and mortality weekly report. Recommendations and reports, 53(RR-12), 1-13. Retrieved from jstor.org/stable/10.2307/24832543

[15] Brown, B.B. (1982). The extent and effects of peer pressure among high school students: A retrospective analysis. Journal of Youth and Adolescence, 11, 121-133.

[16] Brown, B.B., Clasen, D.R. \& Eicher, S.A. (1986). Perceptions of peer pressure, peer conformity dispositions, and self-reported behavior among adolescents. Developmental Psychology, 22 (4), 521-530.

[17] Catz, S. L., Kelly, J. A., Bogart, L. M., Benotsch, E. G., \& McAuliffe, T. L. (2000). Patterns, correlates, and barriers to medication adherence among persons prescribed new treatments for HIV disease. Health Psychology, 19, p.124-133.

[18] CDC. (2009). Diagnoses of HIV infection and AIDS in the United States and dependent areas, HIV Surveillance Report, Volume 21

[19] Chiu, C., Hong, Y., \& Dweck, C. S. (1997). Lay dispositionism and implicit theories of personality. Journal of Personality and Social Psychology, 73, 19-30.

[20] Dijkstra, A., \& De Vries, H. (2000). Self-efficacy expectations with regard to different tasks in smoking cessation. Psychology \& Health, 15(4), p. 501-511.

[21] Dishion, T.J., \& Dodge, K.A. (2005). Peer contagion in interventions for children and adolescents: Moving towards an understanding of the ecology and dynamics of change. Journal of Abnormal Child Psychology, 33, 395-400.

[22] Dweck, C. S. (1999). Self-theories: Their role in motivation, personality

[23] Dweck, C. S. (1999). Self-theories: Their role in motivation, personality and development. Philadelphia: Psychology Press.

[24] Dweck, C. S., \& Leggett, E. L. (1988). A social-cognitive approach to motivation and personality. Psychological Review, 95(2), 256-273.

[25] Emaikwu, S. O. (2012). Fundamental of Education Research Methods and Statistics. Kaduna: Deray Prints Ltd.

[26] Ethiopia MoH (2006). National Adolescent and Youth Reproductive Health Strategy. In: Health F, editor. Addis Ababa, Ethiopia. 2006.

[27] Famutimi Esther RN MN Oluwatoyin, Oyetunde Modupe RN, (2014);PhD O. Risky Sexual Behaviour among Secondary School Adolescents in Ibadan North Local Government Area, Nigeria. IOSR Journal of Nursing and Health Science. 3(3):11.

[28] Feldman, M. A., Ojanen, T., Gesten, E. L., Smith-Schrandt, H., Brannick, M., Totura, C. W., . . Brown, K. (2014). The effects of middle school bullying and victimization on adjustment through high school: Growth modeling of achievement, school attendance, and disciplinary trajectories. Psychology in the Schools, 51, 10461062.

[29] Forman-Alberti A (2015). Facets of peer relationships and their associations with adolescent risk-taking behavior. CYF News December

[30] Hamilton, B. E., Martin, J. A., \& Ventura, S. J. B.(2011): Preliminary data for 2009. National Vital Statistics Reports; 59(3).

[31] Kaplan, P.S. (2004). Adolescence. Boston: Houghton Miffin Company.

[32] Kiran-Esen, B. (2003). Examining the adolescents' smoking according to their peer pressure levels and gender. Educational Sciences: Theory \& Practice, 3 (1), 179-188.

[33] Klarin, M. (2006). Development of children in social context: parents, peers, teachers - context of child development. Jastrebarsko: Naklada Slap.

[34] Lashbrook, J.T. (2000). Fitting in: Exploring the emotional dimension of adolescent peer pressure. Adolescence, 35, 747-757. 
[35] Lebedina Manzoni, M., Lotar, M. \& Ricijaš, N. (2008). Adolescents' susceptibility to peer pressure - challenges of defining and measuring. Annual of Social work, 3, 401-419.

[36] Levinson, R. A. (1982). Teenage women and contraceptive behavior: Focus on self-efficacy in sexual and contraceptive situations. Unpublished $\mathrm{PhD}$ thesis. Stanford, CA: Stanford University

[37] Luthans, F., Avey, J. B., \& Patera, J. L. (2008a). Experimental analysis of a web-based training intervention to develop positive psychological capital. Academy of Management Learning \& Education, 7(2), 209-221. doi: 10.5465/amle.2008.32712618

[38] Luthans, F., Avey, J. B., Avolio, B. J., Norman, S. M., \& Combs, G. M. (2006). Psychological capital development: Toward a micro-intervention. Journal of Organizational Behavior, 27(3), 387-393. doi:10.1002/job.373

[39] Luthans, F., Avey, J. B., Clapp-Smith, R., \& Li, W. (2008b). More evidence on the value of Chinese workers' psychological capital: A potentially unlimited competitive resource. The International Journal of Human Resource Management, 19(5), 818-827. doi: 10.1080/09585190801991194

[40] Madhivanan P, Hernandez A, Gogate A, et al. (2005). Alcohol use by men is a risk factor for the acquisition of sexually transmitted infections and human immunodeficiency virus from female sex workers in Mumbai, India. Sex Transm Dis.;32(11):685-690.

[41] Madise N, Zulu E, Ciera J. (2007). Is poverty a driver for risky sexual behavior? Evidence from National Surveys of adolescents in four African countries. African Journal of Reproductive Health.;11(3): 83-98

[42] Maisto SA, Palfai T, Vanable PA, Heath J, Woolf-King SE. (2012). The effects of alcohol and sexual arousal on determinants of sexual risk in men who have sex with men. Arch Sex Behav.;41(4):971-986

[43] McIntosh, J., MacDonald, F. \& McKeganey, N. (2003). The Initial Use of Drugs in a Sample of Pre-teenage Schoolchildren: the role of choice, pressure and influence. Drugs: education, prevention and policy, 10 (2), 147-158.

[44] McKirnan DJ, Ostrow DG, Hope B. (1996). Sex, drugs and escape: a psychological model of HIV-risk sexual behaviours. AIDS Care.;8(6):655-669.

[45] Molden, D. C., \& Dweck, C. S. (2006). Meaning and motivation. In C. Sansone \& J. M. Harackiewicz (Eds.), Intrinsic and extrinsic motivation: The search for optimal motivation and performance (pp. 131-159). San Diego, CA: Academic Press.

[46] Motl, R. W., Dishman, R. K., Saundres, R. P., Dowda, M., Felton, G., Ward, D. S., \& Pate, R. R. (2002). Examining social-cognitive determinants of intention and physical activity among Black and White adolescent girls using structural equation modelling. Health Psychology, 21, 459-467.

[47] Moulden DC, \& Dweck C.S, (2006). Finding "Meaning" in Psychology

[48] Kruger N., Gouws, E. and Dicker, A. (2011). The Adolescents: An Educational Perspective. Only Study Guide for GED-201W, University of South Africa, Pretoria, South Africa,.

[49] Nwankwo B.O Nwoke, E. A (2009).Risky sexual behaviours among adolescents in Owerri Municipal: predictors of unmet family health needs. Afr J Reprod Health. Mar;13(1):135-45.

[50] Potard, C., Courtois, R., \& Rusch E. (2008). The influence of peers on risky sexual behaviour during adolescence. The European Journal of Contraception \& Reproductive Health Care.

[51] Prochaska, J. O., Norcross, J. C., Fowler, J., Follick, M. J., \& Abrams, D. B. (1992). Attendance and outcome in a worksite weight control program: Processes and stages of change as process and predictor variables. Addictive Behaviors, 17, p.35-45.

[52] Rafael C., Seemeen, S., Edmore, M., \& Odutolu O. (2015). Adolescent Sexual and Reproductive Health in Nigeria. Health, nutrition and population global practice knowledge brief;. World Bank, Washington, DC.
[53] Robers, S., Kemp, J., Truman, J. (2013). Indicators of school crime and safety: 2012 (Report No. 2013-036 / NCJ 241446). Washington, DC: National Center for Education Statistics. from http://nces.ed.gov/pubs2013/2013036.pdf

[54] Roeser, R. W., Eccles, J. S., Sameroff, A. J. (2000). School as a context of early adolescents' academic and social-emotional development: A summary of research findings. The Elementary School Journal, 100(5), 443-471.

[55] Rudolph, K. D. (2010). Implicit theories of peer relationships. Social Development, 19, 113-129.

[56] Santor, D.A., Messervey, D. \& Kusumakar, V. (2000). Measuring peer pressure, popularity, and comformity in adolescent boys and girls: Predicting school performance, sexual attitudes, and substance abuse. Journal of Youth and Adolescence, 29 (2), 163 182.

[57] Savin-Williams, R.C. \& Berndt, T.J. (1990). Friendships and peer relations. In S.S. Feldman \& G.R. Elliot (Eds.), At the threshold: The developing adolescent (pp. 277-307). Cambridge, MA: Harvard University Press.

[58] Sim, T.N. \& Koh, S.F. (2003). A Domain Conceptualization of Adolescent Susceptibility to Peer Pressure. Journal of Research on Adolescence, 13 (1), 57-80.

[59] Stajkovic, A. D., \& Luthans, F. (1998a). Self-efficacy and workrelated performance: A meta-analysis. Psychological Bulletin, 124(2), 240-261. doi: 10.1037/0033-2909. 124.2.240

[60] Stajkovic, A. D., \& Luthans, F. (1998b). Social cognitive theory and self-efficacy: Going beyond traditional motivational and behavioral approaches. Organizational Dynamics, 26(4), 62-74. doi: 10.1016/S0090-2616(98)90006-7.

[61] Steinberg L and Monahan K C (2007). Age differences in resistance to peer influence. Developmental Psychology, 43, 15311543.

[62] Swearer, S. M., Collins, A., Radliff, K. H., Wang, C. (2011). Internalizing problems in students involved in bullying and victimization: Implications for intervention. In Espelage, D. L., Swearer, S. M. (Eds.), Bullying in North American schools (2nd ed., pp. 45-61). New York, NY: Routledge.

[63] UNAIDS, (2014). The gap Report. Geneva, Switzerland.

[64] Urberg, K.A., Luo, Q., Pilgrim, C. \& Degirmencioglu, S.M. (2003). A two-stage model of peer influence in adolescent substance use: individual and relationship-specific differences in susceptibility to influence. Addictive Behaviors, 28, 1243-1256.

[65] Vander Zanden, J.W. (2000). Human Development. New York: The McGraw-Hill Companies.

[66] Wang, R. H., Wang, H. H., \& Hsu, M.T. (2003). Factors associated with adolescent pregnancy - a sample of Taiwanese female adolescents. Public Health Nursing, 20, p.33-41.

[67] Weinstock, H., Berman, S. \& Cates, W. (2000) Sexually transmitted diseases among American youth: Incidence and prevalence estimates. Perspectives on Sexual and Reproductive Health; 36(1): p.6-10.

[68] Wentzel, K. R. (1999). Social-motivational processes and interpersonal relationships: Implications for understanding motivation at school. Journal of Educational Psychology, 91, 7697.

[69] Yeager, D. S., Johnson, R., Spitzer, B., Trzesniewski, K., Powers, J., Dweck, C. S. (2014). The far-reaching effects of believing people can change: Implicit theories of personality shape stress, health, and achievement during adolescence. Journal of Personality and Social Psychology, 106, 867-884.

[70] Yeager, D. S., Lee, H. Y., Jamieson, J. (2016). Integrating implicit theories of personality and the biopsychosocial model of challenge and threat to improve adolescents' stress responses. Psychological Science, 27, 1078-1091. 